Research Article

\title{
Efficient Adaptive Test Method for Textile Development Length in TRC
}

\author{
Regine Ortlepp (iD \\ Research Area Environmental Risks in Urban and Regional Development, \\ Leibniz Institute of Ecological Urban and Regional Development (IOER), Dresden 01217, Germany
}

Correspondence should be addressed to Regine Ortlepp; r.ortlepp@ioer.de

Received 31 January 2018; Accepted 25 June 2018; Published 15 July 2018

Academic Editor: Constantin Chalioris

Copyright (c) 2018 Regine Ortlepp. This is an open access article distributed under the Creative Commons Attribution License, which permits unrestricted use, distribution, and reproduction in any medium, provided the original work is properly cited.

Natural resources can be conserved if we carefully maintain the building stock and indeed extend the useful economic life of buildings. One way to achieve this is to enhance load-bearing structures by repair, restoration, or strengthening. Such upgrading often involves applying a strengthening to existing concrete elements. Over the past decade, textile-reinforced concrete (TRC), encompassing a combination of fine-grained concrete and noncorrosive multiaxial textile fabrics, has emerged as a promising novel alternative for strengthening of conventional steel-reinforced concrete (RC) structures, offering enhanced load-bearing capacity with minimal weight and stiffness change. Although TRC has been extensively researched during the last two decades, the formalization of experimental methods and design standards is still in progress. Attempts to design for good load transfer are often hindered by lack of knowledge regarding bond behaviour. For instance, there are neither standard recommendations nor proofs regarding the required development length of textile fibres in TRC for practical applications up to now. The aim of this work was to provide a test specification, which gives a direct result for the development length (required for the anchorage of a reinforcement, also referred to as "anchorage length") of textile reinforcements in fine-grained concrete-quickly and easily. The aim of this paper was to present the test specification developed in a way that it is useful for the future work of other researchers as well as for construction engineers. Some selected experimental investigations with different textile reinforcements and different bonding properties were performed with the aim of showing the applicability of the proposed adaptive test specification. The results of these tests indicated that conventional AR glass and carbon fabrics without coating required large anchoring lengths. The tests further showed that an additional application of different kinds of coating to textile fabrics greatly increased the reinforcement's resistance to pullout. This is of special interest for carbon fibres, which have a substantially higher strength than AR glass fibres and different bond behaviour; that is, carbon fibres have, by nature, larger development lengths.

\section{Introduction}

1.1. Problem Statement. The world's buildings and infrastructures constitute an enormous public good that must be carefully preserved. This entails, for example, the maintenance and upgrading of structures such as bridges and buildings so that they can be used beyond their intended useful life. An extension of the economic life can greatly contribute to the value retention of these structures. Of course, the demolition and replacement of existing buildings, bridges, and other structures are highly detrimental to the environment in view of the increased consumption of natural resources.

Thus, it is vital to find better ways to upgrade and reuse old structures. Such upgrading can entail modification of the load-bearing structure and thereby lead to additional stresses. As the monolithic structure of many buildings makes it impracticable to replace individual structural members, numerous measures have been developed to strengthen existing reinforced concrete constructions. Over the past decade, textile-reinforced concrete (TRC), encompassing a combination of fine-grained concrete and noncorrosive multiaxial textile fabrics, has emerged as a promising novel alternative for strengthening of conventional steel-reinforced concrete (RC) structures, offering enhanced load-bearing capacity with minimal weight and stiffness change.

Although extensive research was done on TRC within the past years, the formalization of experimental methods and design standards is still in progress. In order to guarantee 
sufficient load-bearing capacity in the TRC-strengthened RC element, the load transfer in the interface between the existing structural element and the strengthening material must be ensured independently of the chosen method of reinforcement. Attempts to design for good load transfer are often hindered by a lack of knowledge regarding the bond behaviour. In contrast to steel reinforcement for RC structures, which follows standardization, textile reinforcement is still under development. Well-known design rules exist for the development length of standardized steel bars. On the contrary, a wide range of textile fabrics exists, including different kinds of fibre materials, knitting methods, and coatings, which still undergoes a very fast development. But the bond properties of textiles in a cementitious matrix are strongly affected by these parameters. Thus, design rules or rather proofs against pullout failure must be limited to a certain textile-matrix configuration. The TUDALIT ${ }^{\circledR}$ initiative [1], which defined design rules, to get an approval of the building authorities for its specified TRC strengthening system is an example for this limitation. However, as long as the majority of TRC materials do not follow standardization, an alternative method is needed for proving the bond capacity (initially focussed on static loading), that is, how to eliminate the possibility of failure due to fabric pullout from the matrix, in research as well as in practical applications. In other words, as long as new textile fabrics appear time and again on the market, an experimental method to determine the development length of such textiles is required, which can be performed quickly and easily and can be used by other researchers and applicants.

1.2. Literature Review. The initial research on TRC was performed in the past 15 years in the Collaborative Research Centre (CRC) 532 at RWTH Aachen [2] and CRC 528 at the Technische Universität Dresden [3], funded by the Deutsche Forschungsgemeinschaft (DFG). Leading research efforts were also done, for instance, in the US (Mobasher [4]), Israel (Peled and Bentur [5], Peled et al. [6]), Brazil (Fidelis et al. [7], de Andrade Silva et al. [8]), Greece (Papanicolaou et al. [9], Triantafillou and Papanicolaou [10], Triantafillou et al. [11]), and Denmark (Blanksvärd and Täljsten [12]). Further on, researchers in Italy (Colombo et al. [13] and Colombo et al. [14]), Spain (Escrig et al. [15]), Belgium (Cauberg et al. [16] and Tysmans et al. [17]), France (Contamine et al. [18]), UK (Tetta et al. [19]), Sweden (Williams Portal et al. [20, 21]), Iran (Kamani et al. [22]), and other countries of the world work meanwhile on the topic of TRC. To sum up all these results, a RILEM task group TC 232-TDT was founded in 2009 to report the most promising test methods and design rules for TRC (Brameshuber [23]). It focussed on test methods for tensile stress-stain behaviour. The outcome was a recommendation on a test method to determine the load-bearing behaviour of tensile specimens made of textile-reinforced concrete (RILEM TC TDT [24]). This recommendation forms the basis for all TRC applications: slender and lightweight structures, such as façade elements (Hegger et al. [25]), bridges (Hegger et al. [26]), and shells (Scheerer et al. [27]), as well as strengthening of existing RC structures. Especially, the research in Germany, Greece, Denmark, and France focusses on strengthening of RC structures. Strengthening for bending (Schladitz et al. [28] and Weiland et al. [29]) and shear (Brückner et al. [30], Schladitz et al. [31], Triantafillou and Papanicolaou [10], and Si Larbi et al. [32]), confinement of columns (Bournas et al. [33], Triantafillou et al. [11], Ombres [34], and Ortlepp et al. [35]), and enhancement of durability (Butler et al. [36] and Michler [37]) are examples of the possible realizations of TRC strengthening. Retrofitting and strengthening of earthquake-damaged or rather vulnerable structures are other worthwhile applications. While TRC strengthening for earthquake resistance using industrial fibres such as AR glass, carbon, or aramide is still on a research stage (Mishra et al. [38] and Koutas et al. [39]) in some largely earthquakeprone countries, strengthening with cheaper fibre types such as polypropylene (pp-mesh) had long been a common method to improve masonry structures, for example, in Pakistan (Dar et al. [40] and Umair et al. [41]). However, despite the widely usage of pp-mesh strengthening, no standardized design guidelines exist for this material (Dar et al. [40]).

One major difficulty of TRC strengthening arises with the end anchoring of the strengthening ( $\mathrm{Si}$ Larbi et al. [42] and Brückner et al. [43]). A sudden system failure can be the result of a bond failure in the anchoring range (Ortlepp et al. [44]). In order to guarantee the load-bearing capacity of the anchoring, sufficient anchoring length must be provided related to all possible bond failure modes. The bond between a TRC strengthening and a RC member can fail in four different ways (Figures 1(b)-1(e)). However, first studies on bond (Brückner et al. [43, 45], Ortlepp and Curbach [46], and Ortlepp et al. [44]) focussed only on the planar bond failure modes (cf. Figures 1(b)-1(d)). The failure of the existing concrete substrate (failure mode 1, Figure 1(b)) and the failure of the bond joint between existing concrete and new TRC overlay (failure mode 2, Figure 1(c)) were well known from externally bonded FRP strengthening means, whose knowledge base is several years ahead of the knowledge base of TRC. An initial finding from the early stage of TRC bond research (Ortlepp et al. [47]) was the existence of a third kind of planar bond failure: a delamination inside the TRC adjacent to the layer of textile reinforcement (failure mode 3, Figure 1(d)). For many years, the research focussed on this "new" failure mode to find the major influencing parameters (Ortlepp [48] and Ortlepp et al. [44]) and calculation models (Ortlepp [49] and Brückner et al. [43]). Due to the properties of AR glass fibres, which were mainly used at this time, delamination was the most critical failure mode hindering the exploitation of the strengthening's load-bearing capacity to its full extent.

Especially, with the use of carbon fibres, the boundary conditions changed. Due to the three times higher E-modulus and the strength of carbon fibres, higher bond stresses occur in the interface between fibres and fine-grained concrete. The result is that a pullout failure (failure mode 4, Figure 1(e)) can become more critical than the planar failure modes (Lorenz and Ortlepp [51]).

From the economic point of view, the load-bearing capacity of the strengthening layer should be used to its fullest extent. Therefore, an optimization of the strengthening system is necessary in the way that the development length for 


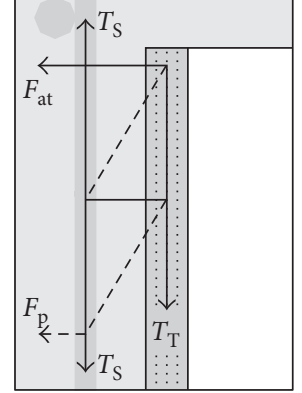

(a)

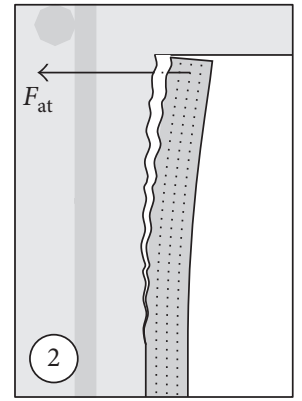

(c) (b)

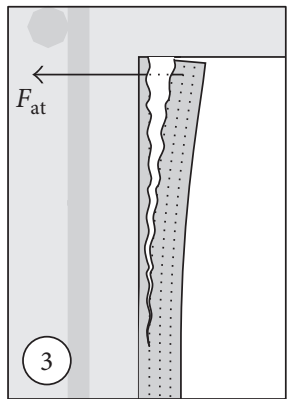

(d)
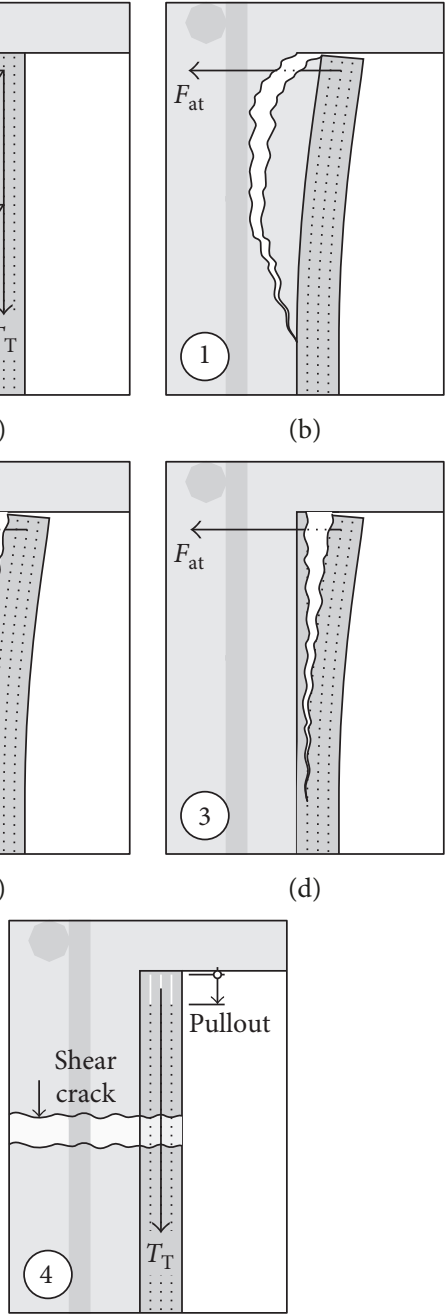

(e)

FIGURE 1: Bond failure modes of a TRC strengthening applied to an RC surface (e.g., shear strengthening of a T-beam) based on the study of Ortlepp et al. [50]. (a) Strut-and-tie model of TRC anchoring. (b) Failure mode: old concrete. (c) Failure mode: joint old-new. (d) Failure mode: delamination. (e) Failure mode: textile pullout.

each of these four failure modes reaches nearly the same value. Except failure mode 1, which is solely dependent on the strength properties of the existing concrete, each of the failure modes can be influenced by changing the boundary conditions. This means, failure mode 2 can be excluded by sufficient roughening of the existing concrete's surface (Ortlepp [49]) and failure modes 3 and 4 can be influenced by different textile fabric configurations (e.g., mesh and weave). Thus, for instance, an open mesh design of the textile can help to prevent a delamination failure (Ortlepp [48] and Brückner et al. [43]). Whereas the knowledge base of the planar failure modes widened in the past years, knowledge relating to the influencing factors on textile pullout is relatively scarce.

It is worth to mention that a lot of research exist in the literature on the pullout behaviour of single fibres. For example, Aljewifi et al. [52] investigated the pullout behaviour of single glass multifilament yarns embedded in a fine-grained cementitious matrix. Banholzer et al. [53, 54] modelled the bond-slip relationship on the basis of onesided single yarn pullout tests. In these tests, a pullout force is applied on the free end of a single yarn embedded in a concrete matrix while measuring resulting displacement. De Andrade Silva et al. [8] investigated the influence of elevated temperatures on the bond behaviour of uncoated and polymer-coated carbon yarns embedded in a concrete matrix using double-sided pullout tests. The investigations showed hardly any effect of elevated temperature in case of uncoated yarns, but in case of coated yarns, both positive and negative effects depending on the preheating load. However, these results can rarely be used for predicting the development length of textile mesh. Butler et al. [36] performed experimental investigations on important mechanisms influencing the durability of the fibre-matrix bond in TRC using double-sided pullout test on slender notched specimens reinforced with a few multifilament AR glass yarns. The yarns were imbedded in matrices of varying alkalinity and hydration kinetics. They found out that the extent of the performance losses with increasing duration of aging depends primarily on the alkalinity of the pore solution in the matrix. These tests do, however, provide some information on the bond behaviour of fibres being processed in textile manufacturing. Just a very few scientists take the effects of different textile fabrication into account, although it is necessary to consider. For example, Williams Portal et al. [20] performed pullout tests of TRC to gain better knowledge of the complex bond behaviour, whereas the pullout test setup and specimen configuration employed were designed based on the double-sided unsymmetrical test by Krüger [55] and Lorenz and Ortlepp [51]. The bond behaviour of basalt TRC was characterized by means of direct pullout tests using different specimen lengths. Based on the measurements, local bond stress-slip curves were calibrated for the basalt and carbon specimens based on the experimental results related to the short specimens, which failed by pullout of the fibres. Applying this local bond stress-slip curve in a simple $1 \mathrm{D}$ bond model demonstrated a reasonable force versus total displacement correlation with the experimental results for the longer embedment lengths as well. The authors state that the pullout test setup presented in their work is suitable to obtain and characterize local bond behaviour for different TRC materials, particularly in the case of short embedment lengths. Also, Peled et al. [56], Krüger [55], and $\mathrm{Xu}$ et al. [57] showed an influence of several types of textile mesh on the bond behaviour of TRC. Lorenz [58] and Williams Portal et al. [20] emphasized the interdependency between textile fabrication and bond properties. For instance, the stitching fibre, which connects the longitudinal and cross yarns of the textile, a coating, and fabrication-induced waviness and variation of the fibres' cross section (as part of a textile, Figure 2), has a significant influence on the load transfer between filament yarns and the surrounding finegrained concrete matrix. Thus, single yarn pullout tests are not sufficient for the derivation of development length of textile fabrics because they do not consider the influence of the textile structure. Consequently, bond properties of TRC can only be determined using textile pullout tests. 


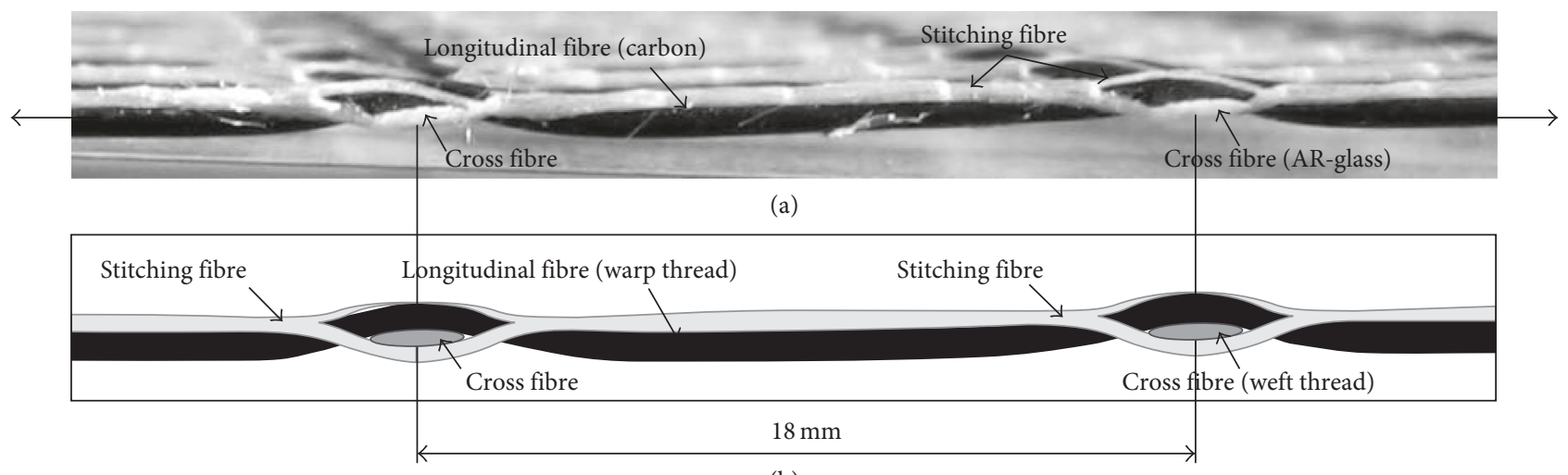

(b)

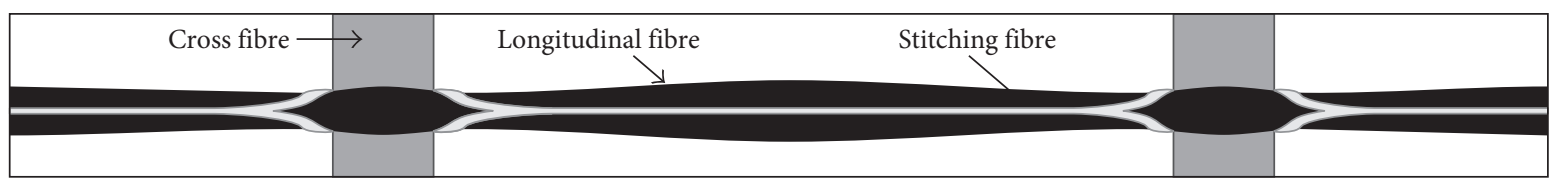

(c)

Figure 2: Undulation and variation of cross section of longitudinal fibres (warp threads) in a textile. (a) Photograph, (b) side view, and (c) top view.

Further on, previous research ended very often with a description of bond-slip relations, which can indicate the energy dissipation in cases of cracking and seismic loading, especially by using short fibres because of their enormous number. Continuous textile fibres require sufficient anchorage for optimum transmission of tensile force into the concrete. Krüger [55] and Williams Portal et al. [20] subsequently use this correlation as an input in nonlinear finite element modelling to simulate the behaviour of tested pullout specimens. However, the following step of deriving a certain development length of continuous fibres is mostly missing. Moreover, determining the development length by using pullout tests with short bond lengths, calibrating local bond stress-slip curves from the measured values, applying those to a bond model, and finally calculating the development lengths, as done by Lorenz [58] and Williams Portal et al. [20], form a cumbersome process. But the simple knowledge of the development length is a prerequisite for engineered design approaches to describe the structural behaviour of the anchoring of bending and shear strengthenings as well as of column confinements (Brückner et al. [30, 43], Ortlepp et al. [59]). An applicable testing method for quick direct obtaining of the development length of textile fabrics embedded in fine-grained concrete matrix of TRC is therefore urgently needed. There is at present not any test method available in international literature that fulfils the aforementioned requirements.

1.3. Aim of the Work. The main aim of this paper was to present an applicable test method for directly obtaining the textile fabric's development length. The article describes the development of this adaptive test setup, starting from a test method for a first screening of textiles and ending up with an improved test method to obtain results that are more exact. Some test series with different parameter variations should show the applicability of both test methods depending on the intended purpose (quick screening or exact determination). Besides, conclusions can be drawn on how different parameters affect the development length. This forms the basis for optimization of the textile fabric's configuration with regard to a possibly short development length, that is, positive effects of bond increasing modifications in the anchoring range on the development length.

The development of the adaptive test method contains two stages. It was first developed for the requirements of AR glass textiles and later expanded to meet the requirements of carbon textiles. This article summarizes the results of the experimental studies of both stages. In order to present the results of the investigations from the first phase in a transparent and reproducible manner, the first test method will be described in addition to the final test method.

\section{Adaptive Test Method for Textile Fabric's Development Length Screening}

2.1. Test Setup. The initial idea was to obtain the development length of textile fabrics in a TRC layer including all influences from the textile fabrication as well as interactions between multiple textile layers within the TRC strengthening as it shall be applied to a structural RC member, for example, a T-beam. Following this idea, the experimental setup for investigating the development length of textile fabrics (Figure 3) was developed on the basis of the uniaxial tension tests recommended by RILEM TC TDT (Hinzen and Brameshuber [60] and RILEM TC TDT [24]), as well as bond tests concerning end anchoring of textile-reinforced strengthening described by Ortlepp et al. [44].

The specimens have a width of $100 \mathrm{~mm}$. In the case of the uniaxial tension tests, the load was introduced at the upper and lower ends of the specimens by clamped anchorage, which was chosen to attain the maximum tensile load of the 


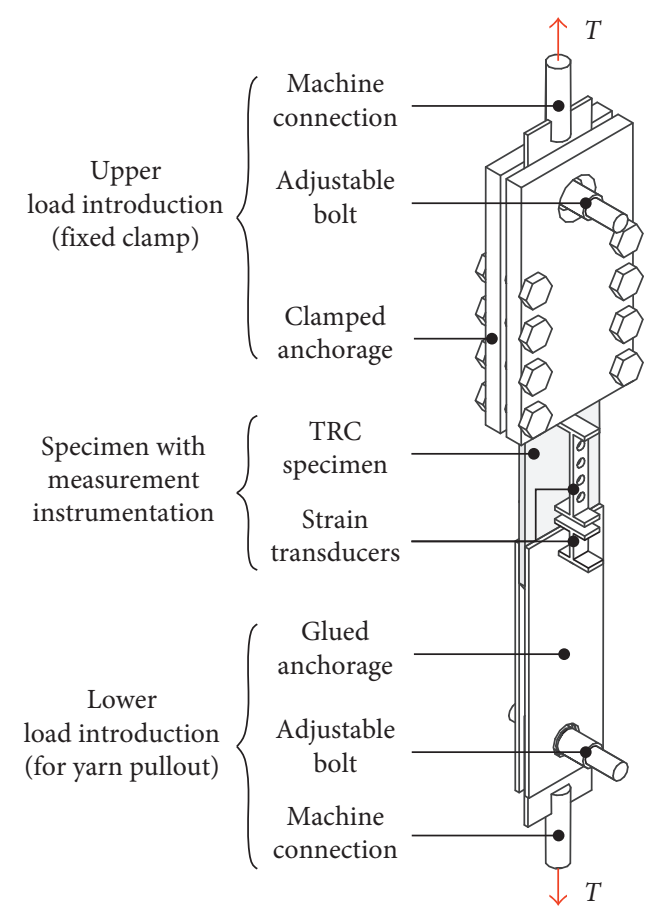

Figure 3: Test setup for the development length of the textile (textile pullout test).

fibres while avoiding a pullout failure from high lateral pressure (Lorenz et al. [61]). Because no lateral pressure but rather adhesive tensile stresses exists in the region of the end anchorage (Ortlepp et al. [44]), the author designed a pullout test setup simulating these adhesive tensile stresses that arise within the range of the end anchorage of a TRC strengthening layer. For this reason, a load introduction by means of glued steel plates was selected at the lower end of the specimen, where pullout was expected to occur (Figures 3 and 4).

2.2. Adjusting the Specimen's Thickness. In order to find the development length including the effect of multiple textile layers as usually applied to structural RC members, the specimen thickness must be able to vary depending upon the number of textile layers examined. Since each fine-grained concrete layer needed to be $2 \mathrm{~mm}$ thick both between and around the textile layers, the total thickness of the strengthening increases by the same amount of thickness as that of the fine-grained concrete intermediate layers. The prototype of the developed test method allows to test specimen thicknesses of up to $25 \mathrm{~mm}$. A variable adjustment of the centre distances of the load-introduction plates was needed to compensate for the various thicknesses of the specimens. A special adjustable bolt was designed (Figures 3 and 5) to be able to precisely manipulate the centre distance between the glued steel plates for each individual specimen.

2.3. Variable Bond Length. The clamping length at the upper end of the specimen was made equal to or greater than that of the glued anchorage to ensure that pullout failure

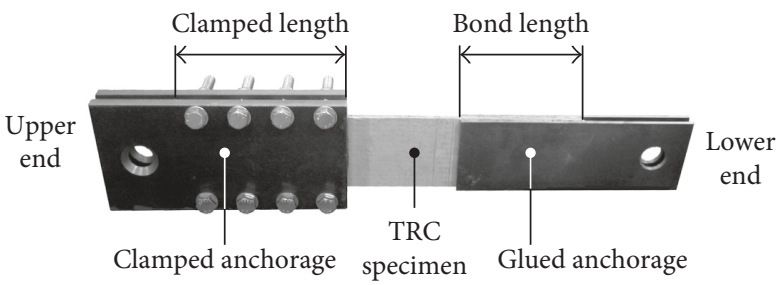

FIgURE 4: Specimen for adaptive testing of textile's development length and anchorage devices.
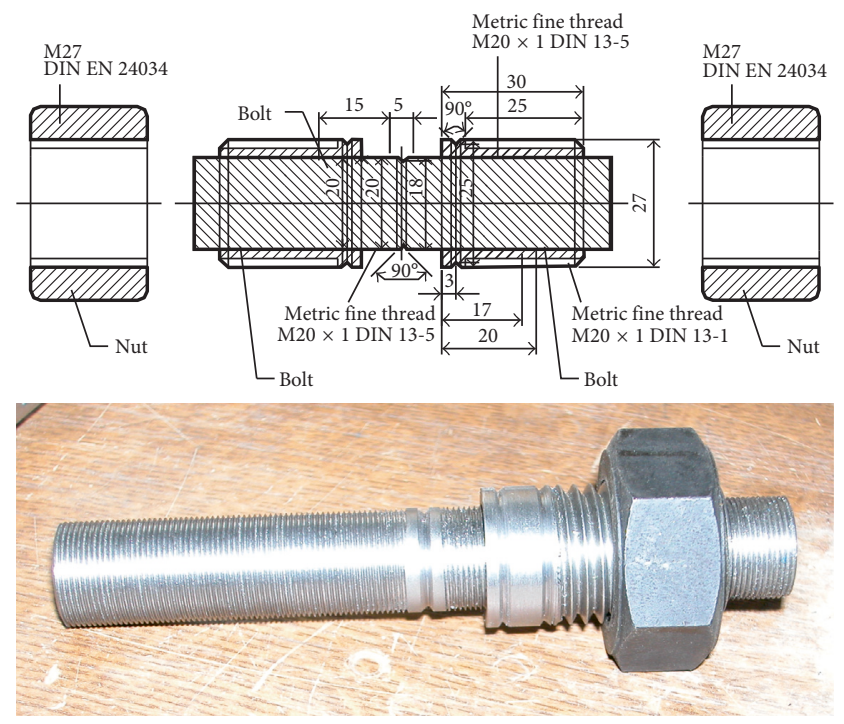

Figure 5: Adjustable bolt.

occurred at the lower end of the specimen. The textile's bond length along the glued anchorage length at the lower end of the specimen can vary depending on the bond properties of the tested textile (Figure 4).

The clearance of the used testing machine limits the maximum length of the specimen, including the loadintroduction devices. Thus, based on the clearance of the machine, a length of $200 \mathrm{~mm}$ was chosen for the clamped anchorage at the first stage of test method development. The bond length at the glued end of the specimen examined varied from 0 to $200 \mathrm{~mm}$ at this stage (Figure 6(a)). This limitation of the maximal anchorage length did initially not serve a problem because TRC strengthening layers made of fibres with common mesh configuration and fineness's up to 1,200 tex (in case of AR glass) and 800 tex (in case of carbon fibres), respectively, have got relatively short development lengths ( $<150 \mathrm{~mm}$ for an existing concrete substrate) as determined by Ortlepp et al. [44]. Textiles with larger development lengths are not suitable for some typical applications where anchorage is crucial for load-bearing capacity in particular, such as shear strengthening of beams (Brückner et al. [30]), anyhow.

At a later stage of the research, this limitation was repealed by the use of another, larger testing machine. This enabled the author to test stronger carbon textile fabrics, such as carbon fibre heavy tow (CFHT) fabrics using larger specimen (Figure 6(b)). 


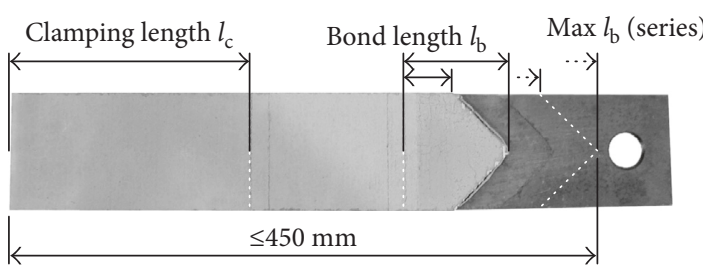

(a)

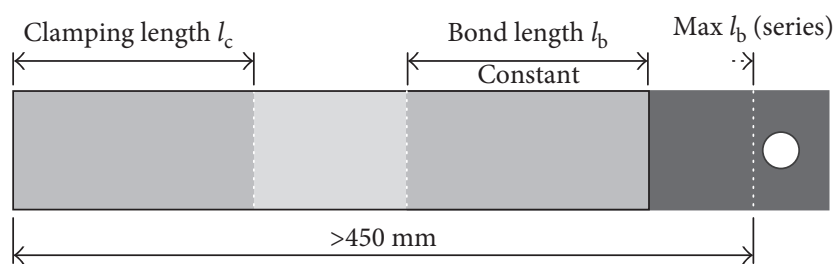

(b)

FIgURE 6: Variable bond length of adaptive pullout specimens. (a) Cone-shaped specimen and (b) rectangle-shaped specimen.

A test series consisted of several specimens. The idea was to minimize the number of specimens per testing series for economic reasons. Using a cone-shaped lower end of the specimen gives an opportunity for such an optimization. Thus, a 45-degree angle (Figure 6(a)) was chosen at the first stage to be the best option. The advantage of this specimen shape was that a range of bonding lengths of $50 \mathrm{~mm}$ (i.e., between edge bond length and middle bond length) could be observed by the use of just one specimen of $100 \mathrm{~mm}$ width.

It is worth to mention here that the cone shape of the specimens had not only advantages. The different bond lengths of the fibres in this type of specimen do not allow for obtaining a sharp force-crack width relationship, but give slightly smeared results. For this reason, a simple rectangle shape of the specimens was chosen later (Figure 6(b)).

2.4. Obtaining the Development Length. On general, fibres, whose bond length (Figure 6) is larger than the development length, fail by tensile failure, whereas fibres whose bond length is smaller will be pulled out of the concrete matrix. That is, specimens with very long bond lengths fail by tensile break of all filament yarns, whereas specimens with short bond lengths fail by complete pullout. The change between the failure modes indicates the development length of the textile fabric in the fine-grained concrete matrix. To find this point, the bond length of the textile must be varied within each series to find the development length of the examined textile and number of layers.

Generally, it is recommendable to estimate the development length of the textile prior to the test based on experience and to use this estimation as starting value for the first test of each series. Following the idea to minimize the number of specimens per series, all specimens of a series were equipped with the anchorage plates not until after knowing the test result of the previous specimen. That is, at first, the anchorage plates were glued onto the first specimen over the estimated development length. Depending on the failure mode obtained, another test must be performed with a variation of the bond length. Using fast-curing twocomponent glue, this procedure does not take much time.

The first batch of test series used the cone-shaped specimen type. In this case, the development length could directly be derived by measuring the protruding fibres from those specimens where a mixed failure occurred (Figure 7).

The second batch of test series used rectangle-shaped specimen, no mixed failure could occur. In this case,

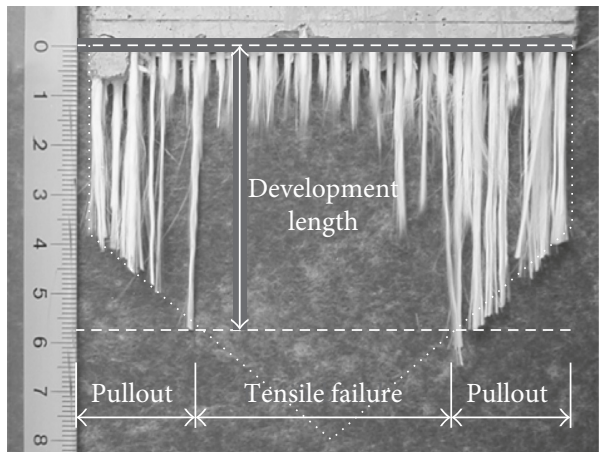

FIGURE 7: Obtaining the development length of cone-shaped specimen.

depending on the ensuing test result of the first test, the anchorage plates of the next specimen were glued over a smaller or longer length in the hope of finding the development length in this tested interval. If one of the tests showed a pullout failure (Figure 8(a)) and the other one a tensile failure (Figure 8(b)), the development length laid in the interval and had to be found by further tests using the interval bisection method. If not, the bond length was increased (in case of two pullout failures) or decreased (in case of two tensile failures) again, until each failure mode had occurred once. Finally, the development length was found using the interval bisection method.

This procedure to find one or two specimen that indicates the development length was used in a similar way with the cone-shaped specimen type.

\section{Experimental Research}

3.1. Production of Test Specimens. The test specimens were produced within steel formwork as plates measuring $1200 \mathrm{~mm} \times 700 \mathrm{~mm}$. The individual textile layers were produced by hand using a method of lamination. The plates stayed in the formwork covered with wet clothes up to three days. After removing the formwork, the specimens were stored in a climatic chamber (65\% relative humidity and temperature of $20^{\circ} \mathrm{C}$ ). Several days prior to testing, the specimens were cut from the plate with a stone saw to fit a width of $100 \mathrm{~mm}$.

Specimens of the 1st batch were cut cone-shaped to varying bond lengths, for example, $30-80 \mathrm{~mm}, 50-100 \mathrm{~mm}$, $\ldots, 150-200 \mathrm{~mm}$, and one to two days prior to the test, the lower load-introduction plates were glued to each of the specimens. Specimens of the 2 nd batch were cut and 


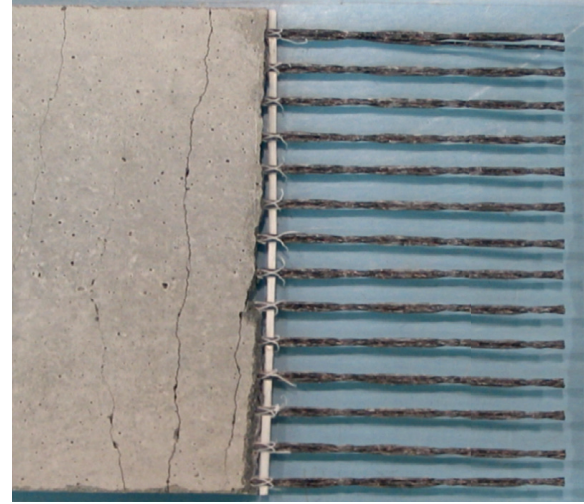

(a)

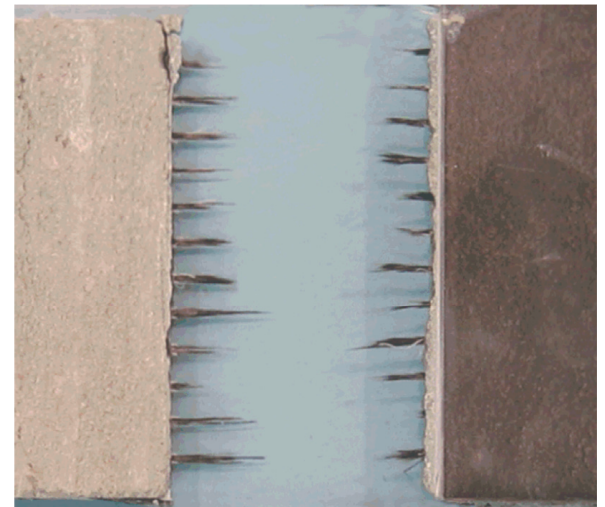

(b)

Figure 8: Obtaining the development length of rectangle-shaped specimen. (a) Pullout failure and (b) tensile failure.

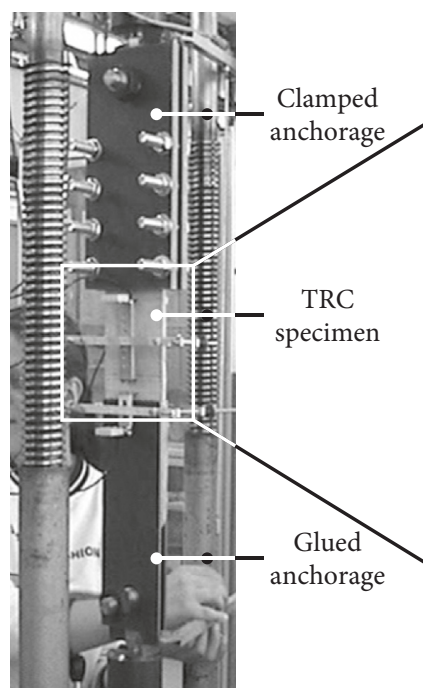

(a)

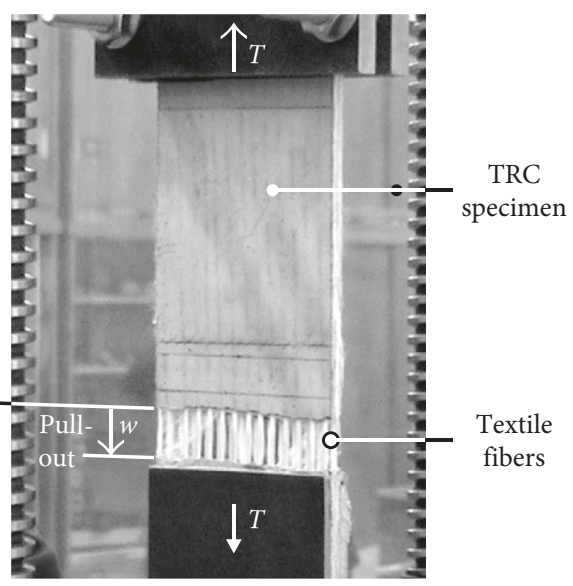

(c)

Figure 9: Measurement instrumentation of the test setup. (a) Test setup, (b) detail of measurement, and (c) textile pullout.

equipped with the load-introduction plates directly prior to each individual test according to the interval bisection method.

3.2. Testing and Measurement Instrumentation. The specimens were tested after 28 days. The tests were conducted within a displacement-controlled, universal testing machine with a maximum loading capacity of $100 \mathrm{kN}$. The control of the displacement was maintained by a separate control-LVDT (linear variable differential transformer). In addition to the tension force $T$, two values of deformation were measured (Figure 9(a)). One of these measured values was the vertical displacement within the range of the free length of the specimen (Figure 9(b)). From this, the stress-strain curve ( $\sigma$ - $\varepsilon$-curve) was determined up to the point of failure. At the same time, the crack width opening $w$ nearest the glued anchorage was measured to obtain the force-crack width opening relationship of the respective textile (Figure 9(c)).

Pairs of strain transducers called "DD1" from HBM (Hottinger and Baldwin Measurement) were used for both deformation measurements. One transducer was placed on the front and the other on the rear of the specimen. Pairs were needed since the specimens were slightly curved as a result of the drying shrinkage process during hardening. Thus, it was possible to minimize the influence of the curvature by averaging the measured strain values determined for each DD1. The strain transducers were removed after reaching the ultimate load to avoid damage resulting from large deformations. Thereafter, the filament yarns of the textile were pulled out completely by manually applying additional deformation (Figure 9(c)) to identify the failure mode of each filament yarn. Finally, the lengths of all remaining protruding fibres of each specimen tested were measured.

\subsection{First Batch of Test Series}

3.3.1. Experimental Program. Five influencing factors were identified as being of potential high importance on the bond behaviour of textile fabrics: 
TABle 1: Parameter specification of 1st batch of specimen.

\begin{tabular}{|c|c|c|c|c|c|c|}
\hline Textile & Material & $\begin{array}{c}\text { Yarn fineness } \\
\text { (tex) }\end{array}$ & $\begin{array}{l}\text { Yarn distance } \\
(\mathrm{mm})\end{array}$ & $\begin{array}{c}\text { Weave, loop length } \\
(\mathrm{mm})\end{array}$ & Coating type & $\begin{array}{c}\text { Percentage of } \\
\text { coating }^{3}\end{array}$ \\
\hline A & AR glass & $1280 / 640$ & $7.2 / 18$ & Pillar-tricot, 3.6 & - & - \\
\hline B & AR glass & $1280 / 640$ & $7.2 / 18$ & Double tricot, 3.6 & - & - \\
\hline $\mathrm{C}$ & AR glass & $640 / 1280$ & $7.2 / 18$ & Double tricot, 3.6 & - & - \\
\hline $\mathrm{D}$ & AR glass & $1200 / 640$ & $7.2 / 18$ & Double tricot, 3.5 & Styrol butadiene & $30 \%$ \\
\hline $\mathrm{E}$ & AR glass & $1200 / 1200$ & $7.2 / 7.2$ & Double tricot, 2.0 & Styrol butadiene & $30 \%$ \\
\hline $\mathrm{F}$ & AR glass & $1200 / 640$ & $7.2 / 10.2$ & Double tricot, 2.0 & Styrol butadiene & $15 \%$ \\
\hline G1 & Carbon & $800 / 800$ & $10.8 / 18$ & Double tricot, 3.5 & Styrol butadiene & $30 \%$ \\
\hline G2a & Carbon & $800 / 800$ & $10.8 / 18$ & Double tricot, 3.5 & Epoxy resin & $30 \%$ \\
\hline G2b & Carbon & $800 / 800$ & $10.8 / 18$ & Double tricot, 3.5 & Epoxy resin & $15 \%$ \\
\hline $\mathrm{H} 1 \mathrm{a}$ & Carbon $^{4}$ & $800 / 640$ & $7.2 / 18$ & Double tricot, 3.5 & Styrol butadiene & $30 \%$ \\
\hline $\mathrm{H} 1 \mathrm{~b}$ & Carbon $^{4}$ & $800 / 640$ & $7.2 / 18$ & Double tricot, 3.5 & Styrol butadiene & $15 \%$ \\
\hline $\mathrm{H} 2$ & Carbon $^{4}$ & $800 / 640$ & $7.2 / 18$ & Double tricot, 3.5 & Epoxy resin & $15 \%$ \\
\hline
\end{tabular}

${ }^{1}$ Between warp/weft yarns; ${ }^{2}$ of stitching fibre; ${ }^{3}$ of organic constituent in suspension; ${ }^{4}$ weft yarns made of AR glass.

(1) Coating (with/without; type)

(2) Amount of coating (portion of organic constituent)

(3) Fibre orientation, that is, longitudinal (warp) or cross fibre (weft)

(4) Fibre type

(5) Textile weaving type (activation of cross fibres for anchoring)

The examined textiles were configured accordingly, to generate information on each of these influencing parameters (Table 1).

3.3.2. Test Results for the Development Length. Table 2 lists the results of all tested specimen of the performed parameter study. The 1st column indicates the specimen number as part of a series, for example, specimen 4.2 means the 2nd specimen from series 4 . Each test series used a separate parameter set. The number of tested specimen per series varied from series to series due to the choice of the starting bond length and the effort of interval bisection method. If the starting point was chosen near the unknown development length and the next bond length has advantageously been adjusted, fewer specimens were required. To arrange the results clearly, the specimens per series are sorted in this table by bond range length.

The column pullout length describes the measured length of the longest protruding fibres. The value given in this column indicates the development length for those specimen which failed by mixed failure. Otherwise, the tested bond length was not long enough to find the development length, namely, none of the fibres failed by fracture (indicated by*). In some cases, the pullout resistance was higher than lateral tensile forces, which caused a delamination failure due to splitting forces as a result of the glued anchorage. Textiles with such a failure mode can be identified as safe against a pullout failure. These textiles are appropriate for the intended use since in many cases only short bond lengths are needed for sufficient anchoring. Considering the different failure modes, which occur using the adaptive testing method, will help to manipulate textile parameters in a way that the failure mode fibre pullout will no longer be considered to be critical.

For this purpose, the results give a deeper insight into the influence of the different parameters; that is, the investigations provide information on the sensitivity of the pullout resistance due to different influencing parameters. Thus, the experimental investigations conducted showed, for instance, that application of a coating to textile-reinforcing fabrics leads to a drastic increase in pullout resistance. Taking AR glass textile as an example, the entire tested bond length of the uncoated textile fabric was pulled out of the concrete matrix, whereas a remarkable reduction in the development length was determined for coated textile fabrics (Figure 10). It should be noted that the maximum test length limited the measured length of the uncoated textile fabric displayed in the diagram. That is, the development length of the uncoated fabric was actually larger than $200 \mathrm{~mm}$. Uncoated textile fabrics were, thus, not suitable as reinforcing material for strengthening layers of structural members that require short development lengths of less than $200 \mathrm{~mm}$.

$\mathrm{Xu}$ et al. [57] stated that coatings applied to previously stitched textile fibres create a ribbed surface that enhances pullout resistance. This enhancement of filament yarns found out by $\mathrm{Xu}$ et al. [57] was limited to the warp threads (longitudinal fibres of the textile fabric). The author's investigations showed, however, also an improvement to the bond due to coating in the weft thread direction (cross fibres of the textile fabric). It is important to know that a stitching fibre did not encase the weft threads (c.f. Figure 2) and could therefore not be responsible for a rib effect. This suggests that, apart from the rib effect of the stitching fibre, another effect is involved in improving the bond.

The author's explanation of this effect is that an increased bond occurred between the filaments from the penetration of the polymer coating into the filament yarns. In case of uncoated AR glass filament yarns, often the internal filaments (core fibres) were essentially pulled out, whereas the sleeve filaments, which were located in direct contact to the fine-grained concrete matrix, showed a tensile failure (core fibre pullout). Also, Krüger [55] already observed a core fibre 
TABLE 2: Test results of 1st batch.

\begin{tabular}{|c|c|c|c|c|c|c|c|}
\hline Specimen & Textile & $\begin{array}{l}\text { Load direction } \\
\text { (parallel to) }\end{array}$ & $\begin{array}{c}\text { Bond range } \\
(\mathrm{mm})\end{array}$ & $\begin{array}{c}\text { Application } \\
\text { method }\end{array}$ & Failure mode & $\begin{array}{l}\text { Pullout length } \\
(\mathrm{mm})\end{array}$ & $\begin{array}{l}\text { Ultimate force } \\
(\mathrm{kN})\end{array}$ \\
\hline 1.1 & $\mathrm{~A}$ & Warp thread & $110-160$ & Laminated & Pullout & $160^{*}$ & 10.03 \\
\hline 1.2 & A & Warp thread & $150-200$ & Laminated & Pullout & $200^{*}$ & 11.37 \\
\hline 2.1 & B & Warp thread & $110-160$ & Laminated & Pullout & $160^{*}$ & 10.42 \\
\hline 2.2 & B & Warp thread & $150-200$ & Laminated & Pullout & $200^{*}$ & 11.43 \\
\hline 3.1 & $\mathrm{C}$ & Weft thread & $150-200$ & Laminated & Pullout & $200^{*}$ & 11.50 \\
\hline 4.1 & $\mathrm{D}$ & Warp thread & $30-80$ & Laminated & Delamination & - & 15.07 \\
\hline 4.2 & $\mathrm{D}$ & Warp thread & $70-120$ & Laminated & Delamination & - & 14.50 \\
\hline 4.3 & $\mathrm{D}$ & Warp thread & $110-160$ & Laminated & Tensile failure & $10^{* *}$ & 15.12 \\
\hline 4.4 & $\mathrm{D}$ & Warp thread & $150-200$ & Laminated & Tensile failure & $10^{* *}$ & 15.16 \\
\hline 5.1 & $\mathrm{E}$ & Weft thread & $30-80$ & Laminated & Delamination & - & 10.93 \\
\hline 6.1 & $\mathrm{E}$ & Warp thread & $30-80$ & Laminated & Delamination & - & 12.67 \\
\hline 6.2 & $\mathrm{E}$ & Warp thread & $110-160$ & Laminated & Tensile failure & $11^{* *}$ & 18.88 \\
\hline 6.3 & $\mathrm{E}$ & Warp thread & $130-180$ & Laminated & Tensile failure & $11^{* *}$ & 19.78 \\
\hline 6.4 & $\mathrm{E}$ & Warp thread & $150-200$ & Laminated & Tensile failure & $11^{* *}$ & 19.72 \\
\hline 7.1 & $\mathrm{~F}$ & Warp thread & $30-80$ & Laminated & Mixed (pullout/tensile) failure & 58 & 13.24 \\
\hline 7.2 & $\mathrm{~F}$ & Warp thread & $110-160$ & Laminated & Tensile failure & - & 14.64 \\
\hline 7.3 & $\mathrm{~F}$ & Warp thread & $150-200$ & Laminated & Tensile failure & - & 16.74 \\
\hline 8.1 & G1 & Warp thread & $50-100$ & Laminated & Pullout & $100^{*}$ & 13.54 \\
\hline 8.2 & G1 & Warp thread & $90-140$ & Laminated & Mixed (pullout/tensile) failure & 110 & 22.06 \\
\hline 8.3 & G1 & Warp thread & $110-160$ & Laminated & Mixed (pullout/tensile) failure & 110 & 21.48 \\
\hline 8.4 & G1 & Warp thread & $150-200$ & Laminated & Tensile failure & - & 19.81 \\
\hline 9.1 & G1 & Warp thread & $70-120$ & Sprayed & Mixed (pullout/tensile) failure & 90 & 16.05 \\
\hline 9.2 & G1 & Warp thread & $70-120$ & Sprayed & Mixed (pullout/tensile) failure & 90 & 15.89 \\
\hline 10.1 & $\mathrm{G} 2 \mathrm{a}$ & Warp thread & $50-100$ & Laminated & Pullout & $100^{*}$ & 12.46 \\
\hline 10.2 & G2a & Warp thread & $70-120$ & Laminated & Pullout & $120^{*}$ & 12.85 \\
\hline 10.3 & $\mathrm{G} 2 \mathrm{a}$ & Warp thread & $90-140$ & Laminated & Pullout & $140^{*}$ & 20.07 \\
\hline 10.4 & $\mathrm{G} 2 \mathrm{a}$ & Warp thread & $110-160$ & Laminated & Mixed (pullout/tensile) failure & 140 & 17.85 \\
\hline 10.5 & G2a & Warp thread & $150-200$ & Laminated & Tensile failure & - & 17.85 \\
\hline 11.1 & $\mathrm{G} 2 \mathrm{~b}$ & Warp thread & $50-100$ & Laminated & Pullout & $100^{*}$ & 7.54 \\
\hline 11.2 & $\mathrm{G} 2 \mathrm{~b}$ & Warp thread & $70-120$ & Laminated & Pullout & $120^{*}$ & 9.59 \\
\hline 11.3 & $\mathrm{G} 2 \mathrm{~b}$ & Warp thread & $90-140$ & Laminated & Mixed (pullout/tensile) failure & 140 & 13.63 \\
\hline 11.4 & $\mathrm{G} 2 \mathrm{~b}$ & Warp thread & $110-160$ & Laminated & Mixed (pullout/tensile) failure & 150 & 14.04 \\
\hline 11.5 & $\mathrm{G} 2 \mathrm{~b}$ & Warp thread & $130-180$ & Laminated & Mixed (pullout/tensile) failure & 150 & 16.85 \\
\hline 11.6 & $\mathrm{G} 2 \mathrm{~b}$ & Warp thread & $150-200$ & Laminated & Tensile failure & - & 19.62 \\
\hline 12.1 & $\mathrm{H} 1 \mathrm{a}$ & Warp thread & $50-100$ & Laminated & Mixed (pullout/tensile)failure & 90 & 12.39 \\
\hline 12.2 & H1a & Warp thread & $70-120$ & Laminated & Mixed (pullout/tensile) failure & 90 & 15.16 \\
\hline 12.3 & Hla & Warp thread & $90-140$ & Laminated & Tensile failure & - & 18.85 \\
\hline 12.4 & $\mathrm{H} 1 \mathrm{a}$ & Warp thread & $110-160$ & Laminated & Tensile failure & - & 22.66 \\
\hline 12.5 & H1a & Warp thread & $150-200$ & Laminated & Tensile failure & - & 22.19 \\
\hline 13.1 & $\mathrm{H} 1 \mathrm{~b}$ & Warp thread & $70-120$ & Laminated & Pullout & $120^{*}$ & 11.81 \\
\hline 13.2 & $\mathrm{H} 1 \mathrm{~b}$ & Warp thread & $90-140$ & Laminated & Mixed (pullout/tensile) failure & 140 & 14.94 \\
\hline 13.3 & $\mathrm{H} 1 \mathrm{~b}$ & Warp thread & $110-160$ & Laminated & Mixed (pullout/tensile) failure & 140 & 17.38 \\
\hline 13.4 & $\mathrm{H} 1 \mathrm{~b}$ & Warp thread & $130-180$ & Laminated & Mixed (pullout/tensile) failure & 140 & 19.36 \\
\hline 13.5 & $\mathrm{H} 1 \mathrm{~b}$ & Warp thread & $150-200$ & Laminated & Tensile failure & - & 19.55 \\
\hline 14.1 & $\mathrm{H} 2$ & Warp thread & $70-120$ & Laminated & Pullout & $120^{*}$ & 9.86 \\
\hline 14.2 & $\mathrm{H} 2$ & Warp thread & $90-140$ & Laminated & Mixed (pullout/tensile) failure & 120 & 11.98 \\
\hline 14.3 & $\mathrm{H} 2$ & Warp thread & $110-160$ & Laminated & Mixed (pullout/tensile) failure & 145 & 11.47 \\
\hline 14.4 & $\mathrm{H} 2$ & Warp thread & $130-180$ & Laminated & Tensile failure & - & 15.41 \\
\hline 14.5 & $\mathrm{H} 2$ & Warp thread & $150-200$ & Laminated & Tensile failure & - & 18.37 \\
\hline
\end{tabular}

${ }^{*}$ Value was limited by the bond range. ${ }^{* *}$ Length of protruded yarns.

pullout of uncoated textiles. The larger the size of the fibres' fineness, the greater is the risk of this failure mode. Core fibre pullout never occurred with coated textiles. Thus, this slight impregnation probably led to an increase in the bond of the filaments within the fibres. Obviously, the improved interrelationship between the sleeve and core filaments resulting from the coating effected a significant decrease of the development length.
Besides this bond improvement, a coating leads to an increased flexural rigidity of the textile fabrics. However, a high flexural rigidity is unfavourable in such cases of strengthening of structural members, where the textile fabric must be wound around the edges of a structural member, such as columns with rectangular cross sections. For this purpose, the textiles need to be more flexible, which can be reached by a smaller amount of polymer components in 

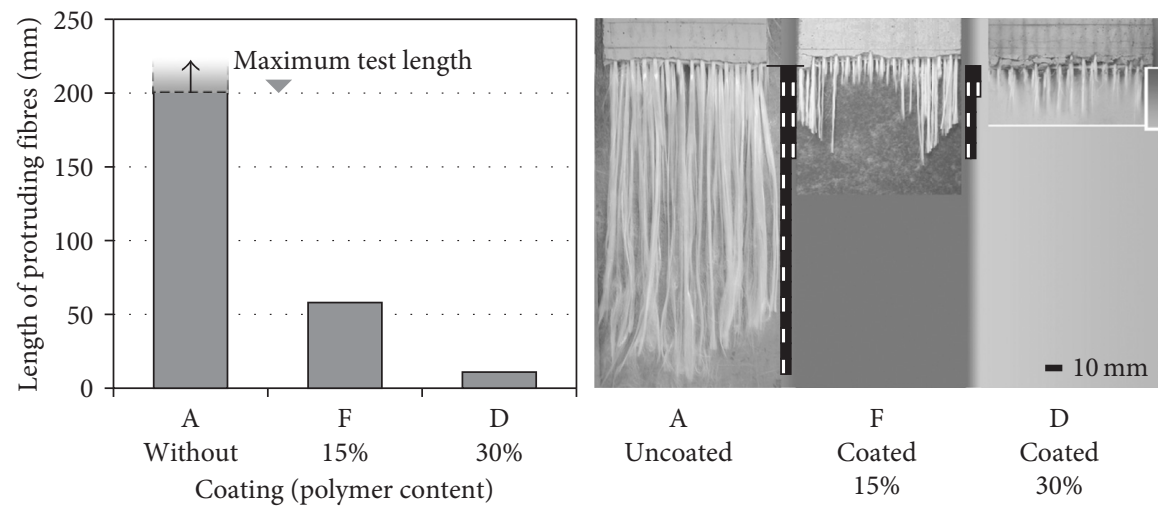

FIGURE 10: Effect of additional coating on the textile's development length.

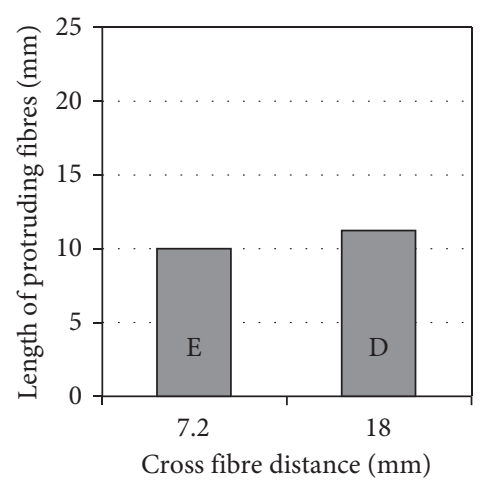

Square textile mesh Rectangular textile mesh
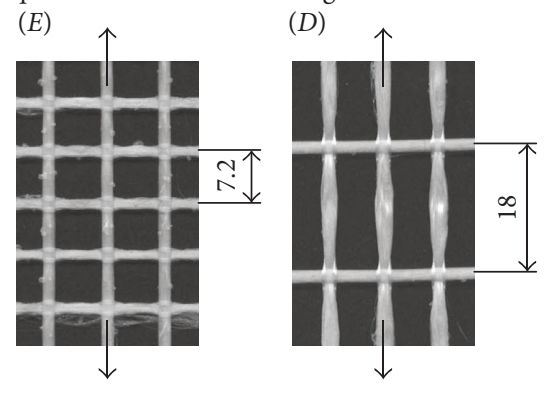

Figure 11: Effect of the cross fibre distance of coated textiles on the textile's development length.

suspension (e.g., $15 \%$ of polymer content instead of $30 \%$ ). The pullout tests on these textiles showed that even this reduced coating leads to a substantial reduction of the development length of the textile fabric, although this effect is less than using larger polymer content (Figure 10).

The layout of the cross fibres is another influencing parameter on the development length. The experimental investigations showed that a decrease in the cross fibre distance caused a bond increase and, thus, a reduction in the development length of the coated textile fabric (Figure 11). According to Krüger [55], the change in the cross section of the longitudinal fibres was responsible for that. The test results obtained by the author's investigations verify this hypothesis. As displayed in Figure 2, a substantial change of the cross section of the longitudinal fibres resulted from cross fibres, in particular, at the intersection points.

A further explanation is that the cross fibres were "glued" to the longitudinal fibres by the coating so that the cross fibres acted as additional anchorage elements for the longitudinal fibres. The number of these anchorage elements increased, thus, given a smaller cross fibre distance. The gluing effect led to a slight decrease of the development length; that is, the parameter cross fibre distance has only a minor effect on the development length.

If carbon fibres are used instead of AR glass fibres for textile-reinforcing fabrics, the bond behaviour changes drastically. While it was observed that a pullout failure could be excluded by an additional coating of AR glass textiles, carbon textiles require substantially larger development lengths. Figure 12 shows a coated AR glass textile in comparison with a coated carbon fibre textile. The coating of both textiles was equal and comprised $30 \%$ polymers in aqueous suspension. The carbon fibres possessed a substantially larger load-carrying capacity than the AR glass fibres despite lower fineness (cf. Table 1). A larger load-carrying capacity induces also larger bond stresses at the fibre-matrix interface, resulting in larger development length. Furthermore, the effect of bond improvement by the polymer-based coating is less for carbon fibres than for AR glass fibres, which is another reason for larger development length of carbon textiles.

The method of application for the fine-grained concrete matrix and the thickness of the TRC are other influencing factors on the development length. While hand laminating is the usual application method on laboratory scale, the practical use on the building site needs more time effective methods such as spraying technique. Professional spraying equipment produces larger layer thickness due to thick material application, resulting in thicker concrete cover compared with hand laminated TRC. As displayed in Figure 13, the development length of the sprayed specimen with a thickness of approximately $15 \mathrm{~mm}$ reduced by about $20 \mathrm{~mm}$ compared with the specimen with the laboratory scale dimensions of $8 \mathrm{~mm}$ thickness. The larger concrete cover gives more space for a tension ring around the fibres because of load transfer, and this is more significant for carbon fibres than for AR glass fibres, due to the carbon fibre's larger load-bearing capacity. 


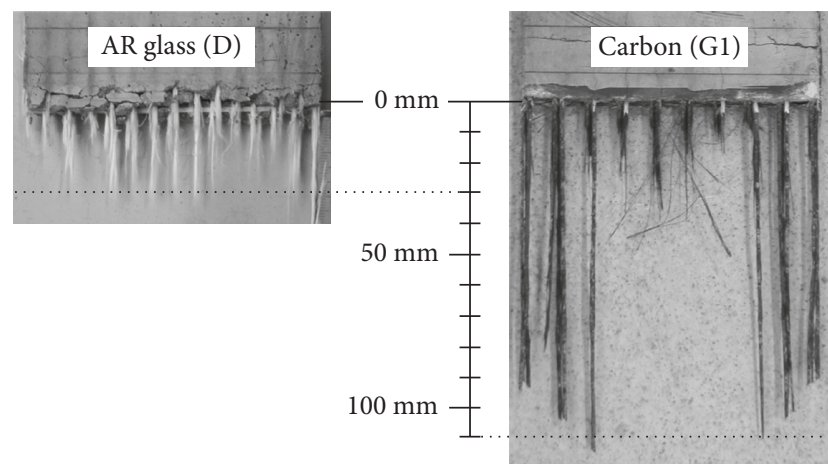

FIGURE 12: Effect of the fibre material on the textile's development length.

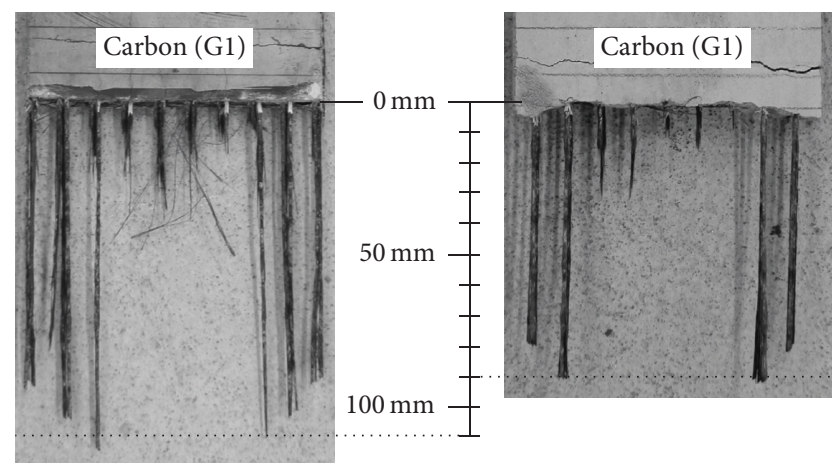

(a)

(b)

FIGURE 13: Effect of the manufacturing process and thickness of the matrix on the textile's development length. (a) Thickness $8 \mathrm{~mm}$, laminated (series 8); (b) thickness $15 \mathrm{~mm}$, sprayed (series 9).

\subsubsection{Test Results for the Force-Crack Width Relationship.} Besides the primary intention of obtaining the development length, the measurement instrumentation (cf. Figure 9) delivers in principle also information on the force-crack width relationship. But caution should be exercised to derive a bond-slip relationship from these measured values. The different bond lengths of the fibres in the cone-shaped specimens lead to uncertainties. Nevertheless, the curves are useful for qualitative comparisons between different parameters. Figure 14 shows as an example the qualitative comparison between uncoated and differently coated textiles. The existence of a coating strongly influences the crack width, whereas the polymer ratio in the coating plays a minor role, especially for small crack widths.

It should, however, be kept in mind that the curves derived from the cone-shaped specimens are not suitable for exact quantification of differences due to the abovementioned uncertainties. To sharpen those results, the author changed the shape of the specimens in the second batch of test series to a rectangular one, where all fibres had the same bond length.

\subsection{Second Batch of Test Series}

3.4.1. Experimental Program. The goal of the second batch of test series was to quantify the influence of different

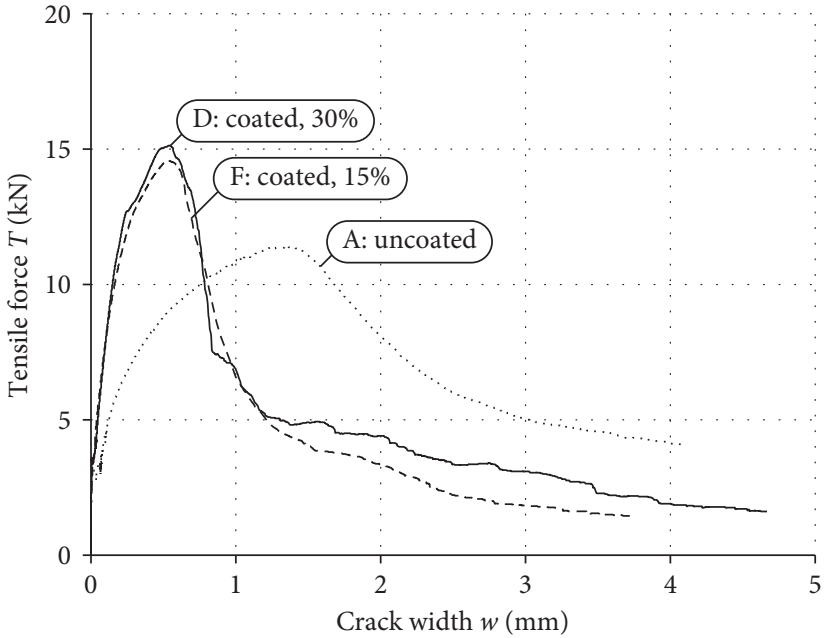

Figure 14: Effect of additional coating.

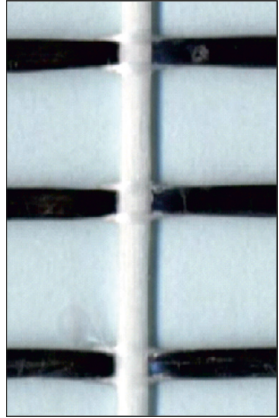

(a)

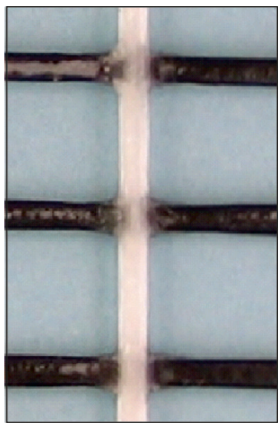

(c)

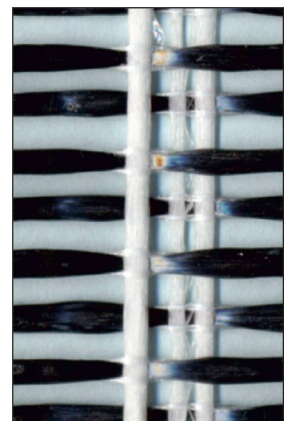

(b)

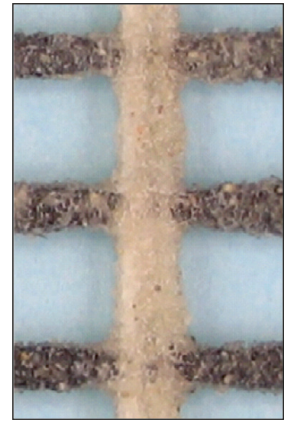

(d)
Figure 15: Tested textiles of the 2nd batch. (a) Reference textile, (b) double layer, (c) epoxy resin, and (d) epoxy resin + sand.

bond-improving measures on the development length. Carbon textile stood in the focus of these investigations because the failure mode textile pullout is found to be more critical in these cases than delamination. Thus, a textile consisting of carbon fibres in load-bearing direction (Figure 15(a)) was used as reference in these test series. The possible reduction of the development length was analysed using different measures. Thus, specimens with double-layer textile (Figure 15(b)), specimens with an additional epoxy resin coating (Figure 15(c)), and specimens with epoxy resin and sand coating (Figure 15(d)) were examined. 


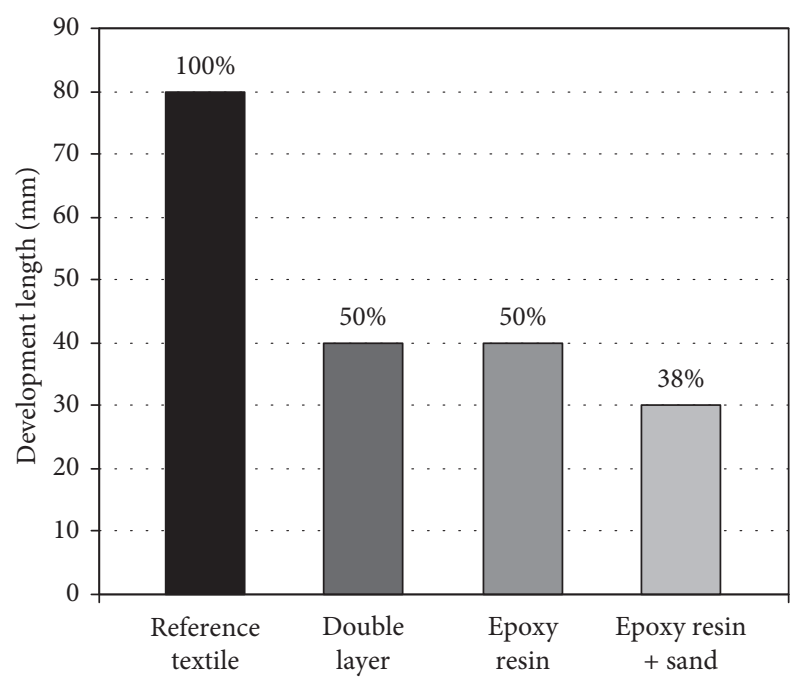

Figure 16: Comparison of the development lengths.

3.4.2. Test Results for the Development Length. The results of the tests carried out to determine the development lengths are represented in Figure 16. Reductions of the development lengths of 50 to $60 \%$ were achieved in comparison with the unmodified reference textile as a result of the bondimproving measures.

As can be seen in Figure 16, simply using a second textile layer to increase the percentage of reinforcement decreases the development length by half as expected. This result seems plausible because splitting the bond force between these two textile layers results in halving the required length for bond force transfer. The application of an epoxy resin coating leads to the same reduction of the development length. Adding sand to the epoxy resin coating reduces the development length further on. Overall, reductions of the development lengths of 50 to $60 \%$ were achieved in comparison with the unmodified reference textile because of the bond-improving measures.

\section{Conclusions}

Lots of influencing factors rule the development length of textile reinforcements in concrete. Reviewing the relevant literature (e.g., the parameter study of Sueki et al. [62]) leads to the conclusion that experimental investigations and analytical descriptions are necessary to understand the bond behaviour and its influencing factors. This is of particular importance during the development of suitable textile fabrics in order to improve their properties. It is highly improbable to grasp all influencing factors and to find a general formula. Therefore, it makes sense to describe the bonding behaviour only for standardized textile structures. Otherwise, experimental investigations are required, which provide suitable information about the bond properties of the nonstandardized textile. Small test specimen as described in Lorenz et al. [51, 58] or Williams Portal [20] is most appropriate for such experiments. Furthermore, more comprehensive analytical approaches will result, if applicable any, in extended complicated formulations not sufficient for the practical application. Therefore, a test setup is needed for easy direct determination of the development length. This is, especially, the case for the practical application of strengthening structures, where engineers need the development length as an input value for the design.

The developed test setup allows quick and easy testing of the development length of textiles embedded in a finegrained concrete matrix. The aforementioned tests have proven their suitability for AR glass textiles and carbon fibre textiles, respectively. The risk of a textile fibre pullout is a problem for carbon textiles, in particular, since very high tensile strengths are being reachable and because of its smooth yarn surface. Thus, bond increasing modifications within the anchorage area with regard to a shortening of the development length gain here special importance. The results of the investigations showed a high potential to enhance the textile fabrics' bond properties. Subsequently applied coatings enhance the internal bond of textiles within a fine-grained concrete matrix. The tested coating techniques are very suitable for reducing the development length of carbon fibre textiles.

\section{Data Availability}

Data underlying the findings are mainly listed in the appendix of Ortlepp [49] (open access).

\section{Conflicts of Interest}

The author declares that there are no conflicts of interest.

\section{Acknowledgments}

The empirical work for this study was funded by the Deutsche Forschungsgemeinschaft (DFG) as a part of the Collaborative Research Centre 528.

\section{References}

[1] TUDALIT eV, Leichter Bauen-Zukunft Formen, 2017, in German, http://tudalit.de/.

[2] Kompetenzzentrum TEXTILBETON, Competence Centre Textile Reinforced Concrete, January 2018, http://www. textilbeton-aachen.de/index.php?id=142?lang=en.

[3] Institute of Concrete Structure, Collaborative Research Centre (CRC, in German: SFB) 528, January 2018, https://tu-dresden. $\mathrm{de} / \mathrm{bu} / \mathrm{bauingenieurwesen/imb/forschung/sfb528.}$

[4] B. Mobasher, Mechanics of Fiber and Textile Reinforced Cement Composites, CRC Press, Boca Raton, FL, USA, 2011.

[5] A. Peled and A. Bentur, "Fabric structure and its reinforcing efficiency in textile reinforced cement composite," Composites Part A Applied Science and Manufacturing, vol. 34, no. 2, pp. 107-118, 2003.

[6] A. Peled, A. Bentur, and B. Mobasher, Textile Reinforced Concrete, CRC Press, Boca Raton, FL, USA, 2017.

[7] M. E. A. Fidelis, F. de Andrade Silva, and R. D. T. Filho, "The influence of fiber treatment on the mechanical behavior of jute textile reinforced concrete," Key Engineering Materials, vol. 600, pp. 469-474, 2014. 
[8] F. de Andrade Silva, M. Butler, S. Hempel, R. D. T. Filho, and V. Mechtcherine, "Effects of elevated temperatures on the interface properties of carbon textile-reinforced concrete," Cement and Concrete Composites, vol. 48, pp. 26-34, 2014.

[9] C. G. Papanicolaou, T. C. Triantafillou, M. Papathanasiou, and K. Karlos, "Textile reinforced mortar (TRM) versus FRP as strengthening material of URM walls: out-of-plane cyclic loading," Materials and Structures, vol. 41, no. 1, pp. 143-157, 2008.

[10] T. C. Triantafillou and C. G. Papanicolaou, "Shear strengthening of reinforced concrete members with textile reinforced mortar (TRM) jackets," Materials and Structures, vol. 39, no. 1, pp. 93-103, 2006.

[11] T. C. Triantafillou, C. G. Papanicolaou, P. Zissimopoulos, and T. Laourdekis, "Concrete confinement with textile-reinforced mortar jackets," ACI Structural Journal, vol. 103, no. 1, pp. 28-37, 2006.

[12] T. Blanksvärd and B. Täljsten, "Strengthening of concrete structures with cement based bonded composites," Nordic Concrete Research, vol. 2, no. 38, pp. 133-153, 2008.

[13] I. G. Colombo, M. Colombo, and M. di Prisco, "Bending behaviour of textile reinforced concrete sandwich beams," Construction and Building Materials, vol. 95, pp. 675-685, 2015.

[14] I. G. Colombo, A. Magri, G. Zani, M. Colombo, and M. di Prisco, "Erratum to: textile reinforced concrete: experimental investigation on design parameters," Materials and Structures, vol. 46, no. 11, p. 1953, 2013.

[15] C. Escrig, L. Gil, E. Bernat-Maso, and F. Puigvert, "Experimental and analytical study of reinforced concrete beams shear strengthened with different types of textile-reinforced mortar," Construction and Building Materials, vol. 83, pp. 248-260, 2015.

[16] N. Cauberg, T. Tysmans, S. Adriaenssens, J. Wastiels, M. Mollaert, and B. Belkassem, "Shell elements of textile reinforced concrete using fabric formwork: a case study," Advances in Structural Engineering, vol. 15, no. 4, pp. 677-689, 2016.

[17] T. Tysmans, S. Adriaenssens, H. Cuypers, and J. Wastiels, "Structural analysis of small span textile reinforced concrete shells with double curvature," Composites Science and Technology, vol. 69, no. 11-12, pp. 1790-1796, 2008.

[18] R. Contamine, A. Si Larbi, and P. Hamelin, "Identifying the contributing mechanisms of textile reinforced concrete (TRC) in the case of shear repairing damaged and reinforced concrete beams," Engineering Structures, vol. 46, pp. 447-458, 2013.

[19] Z. C. Tetta, L. N. Koutas, and D. A. Bournas, "Textilereinforced mortar (TRM) versus fiber-reinforced polymers (FRP) in shear strengthening of concrete beams," Composites Part B: Engineering, vol. 77, pp. 338-348, 2015.

[20] N. Williams Portal, I. F. Perez, L. N. Thrane, and K. Lundgren, "Pull-out of textile reinforcement in concrete," Construction and Building Materials, vol. 71, pp. 63-71, 2014.

[21] N. Williams Portal, K. Lundgren, H. Wallbaum, and K. Malaga, "Sustainable potential of textile-reinforced concrete," Journal of Materials in Civil Engineering, vol. 27, no. 7, 2015.

[22] R. Kamani, M. K. Dolatabadi, and A. A. A. Jeddi, "Flexural design of textile-reinforced concrete (TRC) using warpknitted fabric with improving fiber performance index (FPI)," Journal of The Textile Institute, vol. 109, no. 4, pp. 492-500, 2018.

[23] W. Brameshuber, Textile Reinforced Concrete: State-of-the-Art Report of RILEM Technical Committee 201-TRC: Textile Reinforced Concrete, RILEM, Report 36, RILEM, Bagneux, France, 2006.
[24] RILEM Technical Committee 232-TDT (Wolfgang Brameshuber), "Recommendation of RILEM TC 232-TDT: test methods and design of textile reinforced concrete-Uniaxial tensile test: test method to determine the load bearing behavior of tensile specimens made of textile reinforced concrete," Materials and Structures, vol. 49, no. 12, pp. 4923-4927, 2016.

[25] J. Hegger, C. Kulas, and M. Horstmann, "Realization of TRC façades with impregnated AR-glass textiles," Key Engineering Materials, vol. 466, pp. 121-130, 2011.

[26] J. Hegger, C. Kulas, H. N. Schneider et al., "TRC pedestrian bridge - design, load-bearing behavior and production processes of a slender and light-weight construction," in International RILEM Conference on Material Science, RILEM Publications, pp. 353-364, Bagneux, France, 2010.

[27] S. Scheerer, R. Chudoba, MP. Garibaldi, and M. Curbach, "Shells made of textile reinforced concrete," Journal of the International Association for Shell And Spatial Structures, vol. 58, no. 1, pp. 79-93, 2017.

[28] F. Schladitz, A. Hoffmann, W. Graf, E. Lorenz, and F. Jesse, "Strengthening of a barrel shell with textile reinforced concrete-Part I: dimensioning and design," in Proceedings of the ACI 2010 Spring Convention, Chicago, IL, USA, 2010.

[29] S. Weiland, R. Ortlepp, B. Hauptenbuchner, and M. Curbach, "Textile reinforced concrete for flexural strengthening of RCstructures-Part 2: application on a Hypar concrete shell," in ACI SP-251-3 Design \& Applications of Textile-Reinforced Concrete, ACI, Quebec, QC, Canada, 2008.

[30] A. Brückner, R. Ortlepp, and M. Curbach, "Textile reinforced concrete for strengthening in bending and shear," Materials and Structures, vol. 39, no. 8, pp. 741-748, 2006.

[31] F. Schladitz, A. Brückner, R. Ortlepp, and M. Curbach, "Shear force strengthening of large, reinforced concrete components using Textile Reinforced Concrete (TRC)," in Proceedings of the 18th Congress of the International Glassfibre Reinforced Concrete Association, Ottawa, ON, Canada, 2008.

[32] A. Si Larbi, R. Contamine, E. Ferrier, and P. Hamelin, "Shear strengthening of RC beams with textile reinforced concrete (TRC) plate," Construction and Building Materials, vol. 24, no. 10, pp. 1928-1936, 2010.

[33] D. A. Bournas, P. V. Lontou, C. G. Papanicolaou, and T. C. Triantafillou, "Textile-reinforced mortar versus fiberreinforced polymer confinement in reinforced concrete columns," ACI Structural Journal, vol. 104, no. 6, pp. 740-748, 2007.

[34] L. Ombres, "Confinement effectiveness in concrete strengthened with fiber reinforced cement based composite jackets," in Proceedings of the 8th International Symposium on Fiber Reinforced Polymer Reinforcement for Concrete Structures (FRPRCS-8), Patras, Greece, 2007.

[35] R. Ortlepp, A. Lorenz, and M. Curbach, "Column strengthening with TRC: influences of the column geometry onto the confinement effect," Advances in Materials Science and Engineering, vol. 2009, Article ID 493097, 5 pages, 2009.

[36] M. Butler, V. Mechtcherine, and S. Hempel, "Experimental investigations on the durability of fibre-matrix interfaces in textile-reinforced concrete," Cement and Concrete Composites, vol. 31, no. 4, pp. 221-231, 2009.

[37] H. Michler, Application of Textile Reinforced Concrete at a Silo Rehabilitation, January 2018, https://tu-dresden.de/ bu/bauingenieurwesen/imb/forschung/Forschungsfelder/ TRC-C3/Praxisprojekte/copy6_of_MUSTER?set_language=en.

[38] R. Mishra, J. Militky, N. Gupta, R. Pachauri, and B. K. Behera, "Modelling and simulation of earthquake resistant 3D woven 
textile structural concrete composites," Composites Part B: Engineering, vol. 81, pp. 91-97, 2015.

[39] L. Koutas, S. N. Bousias, and T. C. Triantafillou, "Seismic strengthening of masonry-infilled RC frames with TRM: experimental study," Journal of Composites for Construction, vol. 19, no. 2, 2015.

[40] A. M. Dar, S. M. Umair, M. Numada, and K. Meguro, Experiment Study on Reduction of pp-Band Mesh Connectivity for Retrofitting of Masonry Structure, Institute of Industrial Science, University of Tokyo, Bulletin of ERS, No. 47, Tokyo, Japan, 2014, http://www.ers.iis.u-tokyo.ac.jp/pdf/ersno.47/ 2014-03-no.47-09.pdf.

[41] S. M. Umair, M. Numada, M. N. Amin, and K. Meguro, "Fiber reinforced polymer and polypropylene composite retrofitting technique for masonry structures," Polymers, vol. 7, no. 5, pp. 963-984, 2015.

[42] A. Si Larbi, R. Contamine, and P. Hamelin, TRC and Hybrid Solutions for Repairing and/or Strengthening Reinforced Concrete Beams, in High Performance Fiber Reinforced Cement Composites 6. RILEM State of the Art Reports, G. J. ParraMontesinos, H. W. Reinhardt, and A. E. Naaman, Eds., Vol. 2, Springer, Dordrecht, Netherlands, 2012.

[43] A. Brückner, R. Ortlepp, and M. Curbach, "Anchoring of shear strengthening for T-beams made of TRC," Materials and Structures, vol. 41, no. 2, pp. 407-418, 2008.

[44] R. Ortlepp, U. Hampel, and M. Curbach, "A new approach for evaluating bond capacity of TRC strengthening," Cement and Concrete Composites, vol. 28, no. 7, pp. 589-597, 2006.

[45] A. Brückner, R. Ortlepp, and M. Curbach, "Textile reinforced concrete-applications and bond specifics," in Proceedings of Fib-Symp. Concrete Structures-the Challenge of Creativity (Book of Abstracts and CD-ROM), CEB-FIP, p. 162, Avignon, France, 2004.

[46] R. Ortlepp and M. Curbach, "Bond failure mechanisms of strengthening layers made of textile reinforced concrete," in Proceedings of 13th Congress of the International Glassfibre Reinforced Concrete Association (Book of abstracts and CDROM), Concrete Society and GRCA, Barcelona, Spain, 2003.

[47] R. Ortlepp, S. Ortlepp, and M. Curbach, "Stress transfer in the bond joint of subsequently applied textile reinforced concrete strengthening," in Proceedings of the ixth International RILEM-Symposium-BEFIB 2004, Bagneux, France, 2004.

[48] R. Ortlepp, "The effective area of an adhesive bond of textile reinforced concrete," in CEB-FIP (Hrsg.), JCI (Hrsg.), Concrete Society (Hrsg.): Concrete: 21st Century Superhero-Building a Sustainable Future emap Networks-Book of Abstracts and CD-ROM, CEB-FIP, London, UK, 2009.

[49] R. Ortlepp, Untersuchungen zur Verbundverankerung textilbewehrter Feinbetonverstärkungsschichten für Betonbauteile [Investigations for the Bond Anchoring of Textile Reinforced Fine-Grained Concrete Strengthening Layers of RC-Members], Dresden, Technische Universität, Fakultät Bauingenieurwesen, Institut für Massivbau, Dresden, Germany, 2007, http:// nbn-resolving.de/urn:nbn:de:swb:14-1187166738380-68700.

[50] R. Ortlepp, A. Brückner, and E. Lorenz, "Verbundversagensmechanismen im Verankerungsbereich von textilbewehrten Feinbetonverstärkungsschichten [Bond failure mechanisms in the anchorage range of textile reinforced finegrained concrete strengthening layers]," in Proceedings of the 4th Colloquium on Textile Reinforced Structures (CTRS4), pp. 433-446, Technische Universität Dresden, In-House Publishing, Dresden, Germany, 2009.

[51] E. Lorenz and R. Ortlepp, "Anchoring failure mechanisms of textile reinforced concrete strengthening of RC structures," in
Proceedings of the ACI 2010 Fall Convention, Pittsburgh, PA, USA, 2010.

[52] H. Aljewifi, B. Fiorio, and J. L. Gallias, "Groups of physical parameters influencing the three stages pull-out behavior of glass multi-filament yarns embedded in micro-concrete," in High Performance Fiber Reinforced Cement Composites 6. RILEM State of the Art Reports, G. J. Parra-Montesinos, H. W. Reinhardt, and A. E. Naaman, Eds., Vol. 2, pp. 117-125, Springer, Dordrecht, Netherlands, 2012.

[53] B. Banholzer, W. Brameshuber, and W. Jung, "Analytical simulation of pull-out tests-The direct problem," Cement and Concrete Composites, vol. 27, no. 1, pp. 93-101, 2005.

[54] B. Banholzer, W. Brameshuber, and W. Jung, "Analytical evaluation of pull-out tests-The inverse problem," Cement and Concrete Composites, vol. 28, no. 6, pp. 564-571, 2006.

[55] M. Krüger, Vorgespannter Textilbewehrter Beton (Pre-Stressed Textile Reinforced Concrete), Institut für Werkstoffe im Bauwesen, Univ. of Stuttgart, Stuttgart, Germany, 2004.

[56] A. Peled, S. Sueki, and B. Mobasher, "Bonding in fabriccement systems: effects of fabrication methods," Cement and Concrete Research, vol. 36, no. 9, pp. 1661-1671, 2006.

[57] S. Xu, M. Krüger, H.-W. Reinhardt, and J. Ožbolt, "bond characteristics of carbon, alkali resistant glass, and aramid textiles in mortar," Journal of Materials in Civil Engineering, vol. 16, no. 4, pp. 356-364, 2004.

[58] E. Lorenz, Endverankerung und Übergreifung textiler Bewehrungen in Betonmatrices (End Anchorage and Overlapping of Textile Reinforcements in Concrete), Technische Universität Dresden, Dresden, Germany, 2015, http://nbnresolving.de/urn:nbn:de:bsz:14-qucosa-170583.

[59] R. Ortlepp, A. Lorenz, and M. Curbach, "Geometry effects onto the load bearing capacity of column heads strengthened with TRC," in Proceedings of 2011 fib Symposium: Concrete Engineering for Excellence and Efficiency, pp. 1193-1196, Prague, Czech Republic, 2011.

[60] M. Hinzen and W. Brameshuber, "RILEM TC TDT-232: round robin test on the uniaxial tensile load bearing behaviour of textile reinforced concrete with two specimens types," ibac Short Report 24, no. 165, RWTH Aachen University, Aachen, Germany, 2011, in German, http://publications.rwthaachen.de/record/48108/files/48108_V2.pdf.

[61] E. Lorenz, E. Schütze, F. Schladitz, and M. Curbach, "Textilbeton-grundlegende untersuchungen im überblick," Beton- und Stahlbetonbau, vol. 108, no. 10, pp. 711-722, 2013.

[62] S. Sueki, C. Soranakom, B. Mobasher, and A. Peled, "Pulloutslip response of fabrics embedded in a cement paste matrix," Journal of Materials in Civil Engineering, vol. 19, no. 9, pp. 718-27, 2007. 


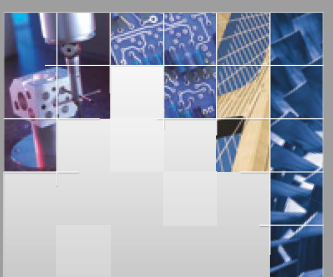

\section{Enfincering}
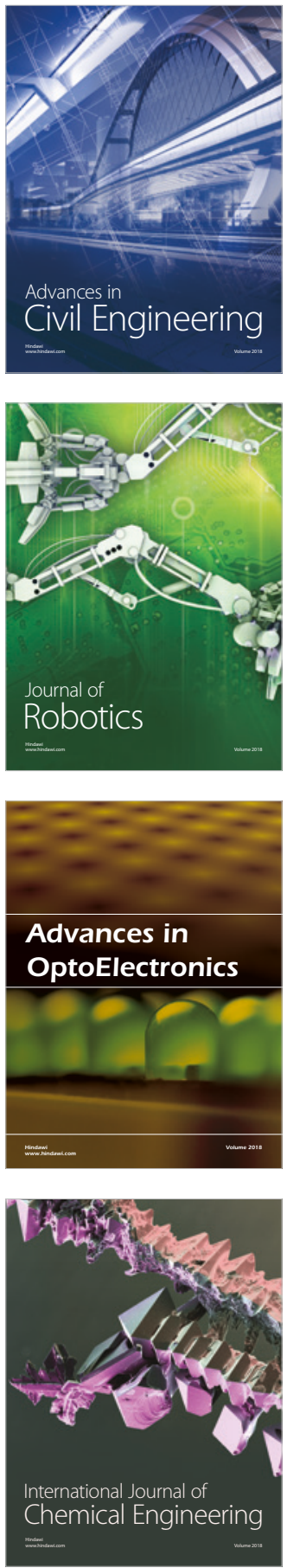

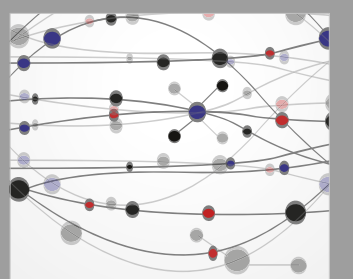

\section{Rotating \\ Machinery}

The Scientific World Journal

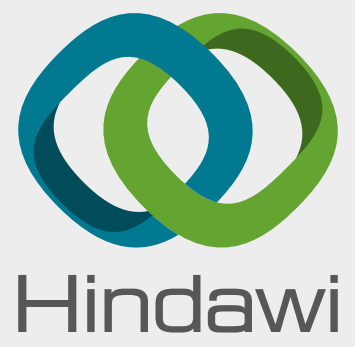

Submit your manuscripts at

www.hindawi.com
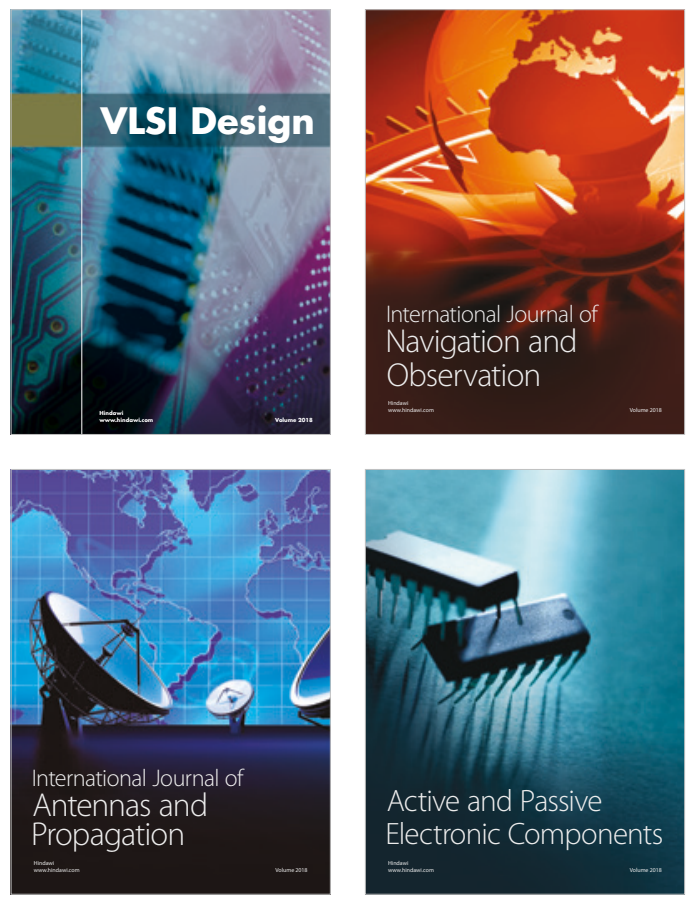
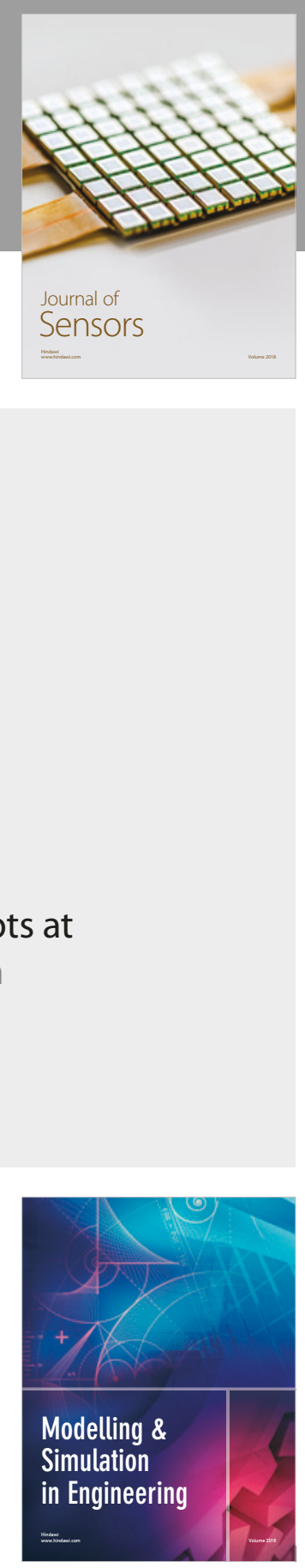

\section{Advances \\ Multimedia}
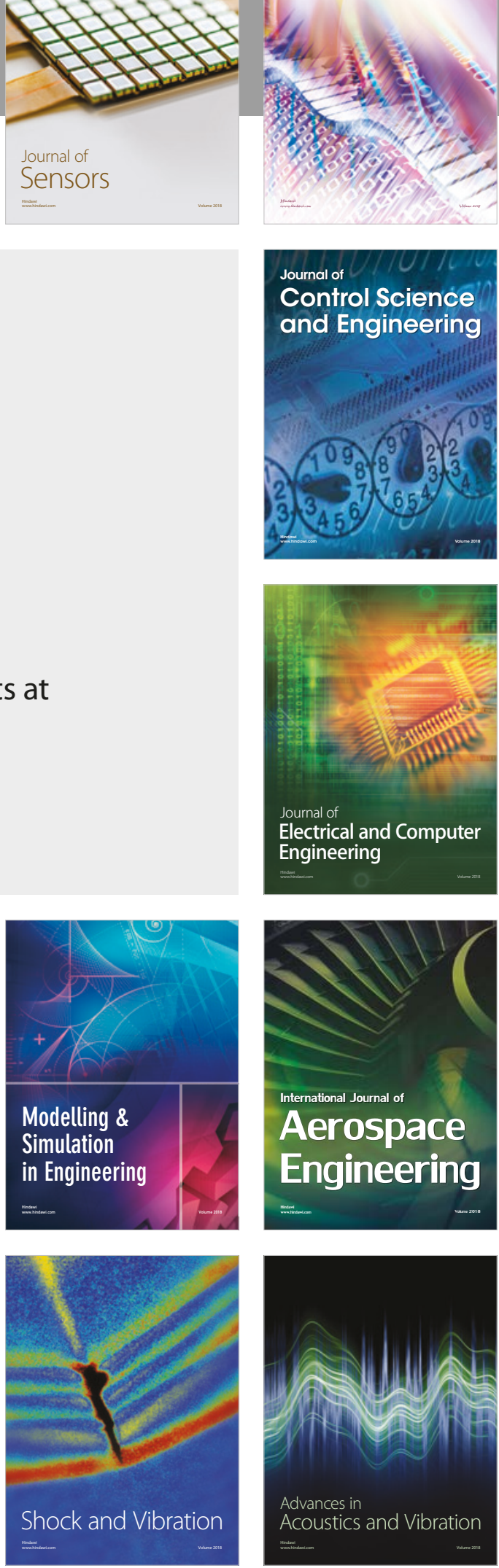